\title{
Effect of different cytokines on mammaglobin and maspin gene expression in normal leukocytes: possible relevance to the assays for the detection of micrometastatic breast cancer
}

\author{
A Ballestrero*, I,2, A Garuti',2, M Bertolotto', I Rocco', D Boy', A Nencioni', L Ottonello' and F Patrone' \\ 'Department of Internal Medicine, Università di Genova, Viale Benedetto XV n. 6, 16132 Genova, Italy
}

In cancer patients, the ability to detect disseminated tumour cells in peripheral blood or bone marrow could improve prognosis and consent both early detection of metastatic disease and monitoring of the efficacy of systemic therapy. These objectives remain elusive mainly due to the lack of specific genetic markers for solid tumours. The use of surrogate tissue-specific markers can reduce the specificity of the assays and give rise to a clinically unacceptable false-positive rate. Mammaglobin (MAM) and maspin are two putative breast tissue-specific markers frequently used for detection of occult tumour cells in the peripheral blood, bone marrow and lymph nodes of breast cancer patients. In this study, it was evaluated whether MAM and maspin gene expression may be induced in the normal blood and bone marrow cells exposed to a panel of cytokines, including chemotactic factors (C5a, interleukin (IL)-8), LPS, proinflammatory cytokines (TNF- $\alpha, \mathrm{IL}-\mid \beta)$ and growth factors (IL-3, granulocyte-macrophage colony-stimulating factor, granulocyte colony-stimulating factor). The experimental data show that all cytokines included in the panel, except for IL-8, were able to induce maspin expression; on the contrary, MAM gene was never induced. These results suggest that MAM is more specific than maspin and that the possible interference of cytokines should be taken into account in interpreting molecular assays for detection of isolated tumour cells.

British Journal of Cancer (2005) 92, 1948- 1952. doi:10.1038/sj.bjc.6602563 www.bjcancer.com

Published online 19 April 2005

(C) 2005 Cancer Research UK

Keywords: mammaglobin; maspin; breast cancer; micrometastasis

In breast cancer patients, like some other epithelial tumours, the presence of occult epithelial cells in the bone marrow or peripheral blood has been assumed as a marker of systemic malignant disease and, as a consequence, in the last two decades several immunocytochemical and molecular methods for detection of disseminated tumour cells have been developed with the aims of improving prognosis, early detection of metastatic disease or of monitoring the efficacy of systemic therapy.

Several studies suggest that these objectives can be achieved with the current assays (Cote et al, 1991; Harbeck et al, 1994; Diel et al, 1996; Smith et al, 2000; Terstappen et al, 2000; Gebauer et al, 2001; Jiang et al, 2002; Ozbas et al, 2003; Pantel et al, 2003) and in a few of them the presence of disseminated tumour cells in bone marrow or peripheral blood is recognised as an independent prognostic factor (Diel et al, 1996; Braun et al, 2000; Stathopoulou et al, 2002). However, the literature reports conflicting results and the clinical value of these assays remains to be proven basically because it is uncertain whether the published assays have enough sensitivity, specificity and consistency to be reliably integrated into prospective studies provided with adequate statistical power

\footnotetext{
*Correspondence: Professor A Ballestrero; E-mail: aballestrero@unige.it 2 These authors contributed to this work equally Received 16 July 2004; revised II February 2005; accepted 9 March 2005; published online 19 April 2005
}

to answer the most relevant clinical questions (Jiang et al, 2002; Ozbas et al, 2003; Pantel et al, 2003). Accordingly, the most recent TNM classification of breast cancer does not consider the lymph nodes harbouring isolated tumour cells as positive, but it simply suggests reporting this information, together with the method of detection, in order to facilitate data collection (Singletary et al, 2002).

The molecular methods are mainly based on a qualitative reverse transcriptase polymerase chain reaction (RT-PCR) identification of breast tissue-related mRNA sequences and show, in experimental models, a sensitivity in the range of $1: 10^{6}-10^{7}$, which is generally higher than immunocytochemistry (Smith et al, 2000; Jiang et al, 2002).

Unlike haematological tumours, the crucial limitation of the molecular approach in breast cancer, as well as in other solid tumours, is the lack of a tumour-specific genetic marker that has induced the search for surrogate epithelial markers under the assumption that they are not expressed in mesenchymal cells. However, there are several factors such as pseudogenes, background gene expression and aberrant expression of epithelial genes in mesenchymal cells under several physiological or physiopathological conditions that can reduce the specificity of the assay and give rise to an unacceptable incidence of falsepositive results (Zippelius et al, 1997; Jung et al, 1998, 1999; Ruud et al, 1999; Krüger et al, 2001; Jiang et al, 2002). Mammaglobin (MAM) and maspin are markers of major interest because some 
evidence indicates that they have a stronger relationship with breast tissue than several other epithelial markers such as cytokeratins, CEA and MUC-1 (Luppi et al, 1996; Zach et al, 1999; Grünewald et al, 2000; Ballestrero et al, 2001; Corradini et al, 2001; Silva et al, 2002; Zehentner and Carter, 2004).

Human MAM is a small epithelial secretory protein detectable in normal and pathological mammary tissue. It has a relative breastspecific expression because it is also detectable in ovary, endometrial and eccrine sweat gland tissues (Watson and Fleming, 1996; Grünewald et al, 2002; Sjodin et al, 2003).

Maspin is a serine protease inhibitor with tumour-suppressive activity due to its ability to inhibit metastatic tissue invasion, angiogenesis and to sensitise tumour cells to apoptosis (Zou et al, 1994; Sheng et al, 1996; Zhang et al, 2000; Cher et al, 2003; Liu et al, 2004). Maspin is also expressed in prostatic cells and other tissues (Pemberton et al, 1997).

Although both MAM and maspin are frequently used for detection of occult tumour cells in peripheral blood, bone marrow and lymph nodes (Luppi et al, 1996; Zach et al, 1999; Grünewald et al, 2000; Ballestrero et al, 2001; Corradini et al, 2001; Silva et al, 2002; Zehentner and Carter, 2004), their specificity has been questioned by some authors (Min et al, 1998; Merrie et al, 1999; López-Guerrero et al, 1999; Suchy et al, 2000).

Taking into account that the ectopic transcription of epithelial mRNA sequences is a decisive factor for the assay's specificity, in this article it has been evaluated whether certain biological factors may induce MAM and/or maspin expression in mesenchimal cells.

Reverse transcriptase polymerase chain reaction was used to evaluate the expression of MAM and maspin in normal blood and bone marrow cells exposed to several cytokines, chemokines and growth factors involved in the regulation of chemotaxis, inflammation and haematopoiesis.

\section{MATERIALS AND METHODS}

\section{Tissue samples, cell culture and cytokine stimulation}

Samples from 10 non-neoplastic mammary tissue biopsies and from 12 histologically confirmed breast cancer specimens (10 primary tumours and 2 liver metastases) were used as positive control together with the tumour cell line MCF-7 expressing both MAM and maspin genes (Luppi et al, 1996; Krüger et al, 2001). The tissue specimens were frozen in liquid nitrogen within $60 \mathrm{~min}$ from surgical removal and kept frozen until tissue homogenisation prior to RNA extraction.

Bone marrow specimens $(3-5 \mathrm{ml})$ from 35 healthy bone marrow donors were used as negative controls to test the specificity of the RT-PCR assays. Bone marrow specimens from patients with malignant haematological disease, that is, 10 non-Hodgkin's lymphomas (NHL), five multiple myeloma (MM) and two acute myeloid leukaemias (AML), were also tested for the MAM and maspin transcript expression. Peripheral blood samples (15$20 \mathrm{ml}$ ) were also obtained from 35 healthy volunteers.

Polymorphonuclear (PMN) and mononuclear (Mono) cells harvested from the bone marrow and peripheral blood of 10 healthy donors were used for in vitro cytokine stimulation experiments.

Polymorphonuclear and Mono cells were isolated by means of dextran (Solplex 70 Società Italiana Farmaceutici, Verona, Italy) sedimentation and subsequent centrifugation on a Ficoll-Hypaque (F.H.Pharmacia, Uppsala, Sweden) density gradient. Contaminating erythrocytes were removed by hypotonic lysis. The cells were washed three times with PBS and cultured at $5 \times 10^{6} \mathrm{ml}^{-1}$ in RPMI 1640 with HEPES $25 \mathrm{mM}$ medium (EuroClone, UK) supplemented with $10 \%$ FCS (ICN, Milano, Italy), 1\% L-glutamine (200 mM, Irvine Scientific) and $1 \%$ antibiotics (penicillin $5000 \mathrm{U} \mathrm{ml}^{-1}$ and streptomycin $5000 \mu \mathrm{g} \mathrm{ml}^{-1}$, Gibco Lifethecnology, USA).
Human recombinant cytokines, growth factors and chemotactic factors were added at the following concentration: INF- $\tilde{a}$ $100 \mathrm{U} \mathrm{ml}^{-1}$ (ICN, Milano, Italy), hr-tumour necrosis factor alfa (TNF- $\alpha$ ) $10 \mathrm{ng} \mathrm{ml}^{-1}$ equal to $200 \mathrm{U} \mathrm{ml}^{-1}$ (ICN, Milano, Italy), hr-72 amino acids interleukin-8 (IL-8) $10{\mathrm{U} \mu \mathrm{g}^{-1}}^{-1} 10^{-7} \mathrm{M}$ (Biosource International, CA, USA), hr-interleukin-1 $\beta$ (IL-1) $10 \mathrm{ng} \mathrm{ml}^{-1}$ equal to $1000 \mathrm{U} \mathrm{ml}^{-1}$ (Biosource International, CA, USA), hr-interleukin3 (IL-3) $10 \mathrm{ng} \mathrm{ml}^{-1}$ equal to $1000 \mathrm{U} \mathrm{ml}^{-1}$ (Biosource International, CA, USA), hr-granulocyte-macrophage colony-stimulating factor (GM-CSF) $10 \mathrm{ng} \mathrm{ml}^{-1}$ (Genzyme, Cambrige, MA, USA), hrgranulocyte colony-stimulating factor (G-CSF) $10 \mathrm{ng} \mathrm{ml}^{-1}$ (Lenograstim, Italfarmaco, Italy), LPS Escherichia coli 011:B4 $10 \mu \mathrm{g} \mathrm{ml}^{-1}$ (Calbiochem-Novabiochem Corporation, Darmstadt Germany), hr-Complement C5a $10^{-7} \mathrm{M}$ (Sigma Chemical Co, St Louis, MO, USA).

Leukocytes were incubated with culture medium alone or cytokines for 4, 8, 20, 72 and $96 \mathrm{~h}$. Each test was performed in triplicate and each sample was considered positive if at least two of the three tests were positive.

\section{cDNA synthesis and RT-PCR for MAM and maspin}

Total RNA was extracted using Trizol solution according to the manufacturer's instructions. In all, $1 \mu \mathrm{g}$ of total RNA was reverse transcribed as described previously (Ballestrero et al, 2001).

Before amplification, all the cDNA samples were tested using a standard protocol to amplify a gene-specific $\mathrm{ABL}$ sequence as positive control (Ballestrero et al, 2001).

Mammaglobin RT-PCR assay was performed as follows. The external primers used were MG-1 5'-gAAgTTgCTgATggTCCT CATgCTggC- $3^{\prime}$ and MG-2 5'-CTCACCATACCCTgCAgTTCTgT gAgC-3'. The nested primers were MG-3 5'-CTCCCAgCACTgCTAC gCAggCTC-3' and MG-4 5'-CACCTCAACATTgCTCAgAgTTTCAT CCg-3' (Zach et al, 1999). The lengths of the primary and reamplification products were 326 and $203 \mathrm{bp}$, respectively. The samples were subjected to 30 cycles of amplification $\left(30 \mathrm{~s}\right.$ at $95^{\circ} \mathrm{C}$, $30 \mathrm{~s}$ at $62^{\circ} \mathrm{C}$ and $30 \mathrm{~s}$ at $72^{\circ} \mathrm{C}$ ) and the second amplification was carried out with $3 \mu \mathrm{l}$ of the first reaction product under the same conditions as the first reaction.

Maspin nested PCR analysis was performed as reported previously (Ballestrero et al, 2001).

In all, $10 \mu \mathrm{l}$ of the RT-PCR reactions were electrophoresed on a $2 \%$ agarose gel and stained with ethidium bromide for visualisation under UV light.

\section{Statistical analysis}

Confidence intervals were evaluated according to the Miettinen (1970) test.

\section{RESULTS}

Detection, specificity and sensitivity of MAM and maspin transcripts

Mammaglobin and maspin transcripts were detected by the nested RT-PCR method in each positive control tissue, 10 non-neoplastic mammary tissue samples, 10 primary $\mathrm{BC}$ and two liver metastases and the mammary tumour cell line MCF-7.

To determine the specificity of the two RT-PCR assays, specimens from both 35 bone marrow and 35 peripheral blood normal donors were evaluated.

The MAM and maspin transcripts were negative in every specimen, even after reamplification with nested primers. Thus, test specificity was $100 \%$ with a $95 \%$ confidence interval ranging from 90 to $100 \%$, given these sample sizes.

In $40 \%$ of the samples from the bone marrow of patients with haematological malignancies an 'illegitimate' maspin transcription 
was observed, whereas MAM transcript was undetectable (Table 1 and Figure 1).

In order to assess the sensitivity of the assay, a mixing study was performed using serial dilutions of the mammary carcinoma cell line MCF-7 in peripheral blood Mono cells from healthy volunteers. By using this approach, the nested primer RT-PCR assay was able to detect one MCF-7 cell mixed with $10^{7}$ normal cells, for both MAM and maspin assays according to previously published data (Luppi et al, 1996; Zach et al, 1999; Ballestrero et al, 2001) (data not shown).

\section{Effect of chemotactic factors, cytokines and growth factors on maspin and MAM gene expression}

Bone marrow and peripheral leukocytes can be exposed in different physiological and physiopathological conditions to several cytokines that could induce expression of epithelial markers in the absence of true contamination by epithelial cells.

To investigate this possibility, the expression of MAM and maspin was evaluated in PMN and Mono cells exposed in vitro to a panel of cytokines including chemotactic factors (C5a, IL-8), LPS

Table I Detection of MAM and maspin mRNA in breast tissues, bone marrow and peripheral blood control specimens

\begin{tabular}{|c|c|c|c|}
\hline Sample source & $\begin{array}{l}\text { No. of } \\
\text { samples }\end{array}$ & $\begin{array}{c}\text { No. MAM } \\
\text { positive }\end{array}$ & $\begin{array}{c}\text { No. maspin } \\
\text { positive }\end{array}$ \\
\hline Non-neoplastic breast tissue & 10 & 10 & 10 \\
\hline Primary breast carcinoma & 10 & 10 & 10 \\
\hline Breast carcinoma metastases & 2 & 2 & 2 \\
\hline Normal bone marrow & 35 & 0 & 0 \\
\hline Normal peripheral blood & 35 & 0 & 0 \\
\hline Pathologic bone marrow ${ }^{a}$ & 17 & 0 & 7 \\
\hline
\end{tabular}

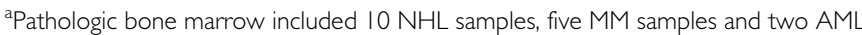
samples.

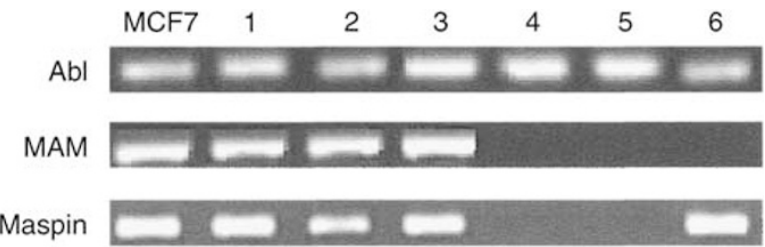

Figure I Electrophoretic analysis in a $2 \%$ agarose gel of MAM and maspin RT-PCR fragments obtained from different tissues. ABL: Abelson transcript, this sequence was used as housekeeping gene; MCF7: positive control; I: non-neoplastic breast tissue; 2: primary breast carcinoma; 3 : breast carcinoma metastases; 4: normal bone marrow; 5: normal peripheral blood; 6: pathologic bone marrow (NHL). pro-inflammatory cytokines (TNF- $\alpha$, IL-1 $\beta$ ) and growth factors (IL-3, GM-CSF, G-CSF).

Mammaglobin and maspin were never expressed in control samples where PMN and Mono cells were exposed to culture medium alone. Otherwise, in experiments with cytokines, all factors, with the exception of IL-8, were able to consistently induce the expression of maspin gene in either bone marrow or peripheral blood leukocytes (Table 2).

Both bone marrow PMN and Mono cells were sensitive to TNF$\alpha$, LPS, C5a, IL-1 and IL-3. Granulocyte colony-stimulating factor and INF- $\tilde{a}$ were able to stimulate bone marrow PMN and Mono cells, respectively.

The effects of cytokines on peripheral blood cells were more selective.

LPS was able to induce maspin expression in PMN, C5a and GM-CSF in Mono cells and IL-3 in both. The electrophoretic analysis of one representative experiment is reported in Figure 2.

The kinetic of expression was different between PMN and Mono cells; in fact maspin mRNA was detectable after $4 \mathrm{~h}$ of incubation in PMN and after 4 days in Mono cells. Interestingly, a longer incubation period, that is, 8 and $20 \mathrm{~h}$, resulted in a downregulated expression of maspin by PMN.

On the contrary, the expression of MAM was never induced in PMN or Mono cells from either bone marrow or peripheral blood even when exposition to cytokines was prolonged to 4 days.

\section{DISCUSSION}

The ability to detect the systemic disease in early-stage solid tumours has, theoretically, a sound biological foundation and could consent a rational clinical approach to the neoplastic patients in terms of both prognosis and treatment planning.

In recent years the presence of occult epithelial cells in bone marrow or peripheral blood has been assumed as a marker of systemic malignant disease in spite of the current immunocytochemical and molecular assays not giving information about the clonogenic potential of detected tumour cells. This assumption is apparently supported by some prospective studies suggesting that the presence of isolated tumour cells in bone marrow or peripheral blood is an independent prognostic factor (Diel et al, 1996; Braun et al, 2000; Stathopoulou et al, 2002). However, the literature reports conflicting results; so this subject is still under discussion (Jiang et al, 2002; Ozbas et al, 2003; Pantel et al, 2003).

Compared with immunocytochemistry and Southern or Northern blotting methods, RT-PCR assays are relatively easy and straightforward to perform, have a high sensitivity rate and are suitable for analysing large numbers of cells. However, due to the lack of tumour-specific genetic alterations, the RT-PCR-based methods rely on the amplification of surrogate epithelial markers that can give rise to false-positive results as a consequence of several physiological or physiopathological factors (Zippelius et al,

Table 2 Maspin expression induced by cytokines in bone marrow and peripheral blood cells from 10 healthy volunteers

\begin{tabular}{|c|c|c|c|c|c|c|c|c|c|c|}
\hline & Neg. control & TNF- $\alpha$ & LPS & $\mathbf{C 5 a}$ & IL-I & IL-3 & IL-8 & G-CSF & GM-CSF & $\gamma$ IFN \\
\hline$A B L$ & + & + & + & + & + & + & + & + & + & + \\
\hline \multicolumn{11}{|c|}{ Bone marrow } \\
\hline $\mathrm{PMN}$ & - & + & + & + & + & + & - & + & - & - \\
\hline Mono & - & + & + & + & + & + & - & - & - & + \\
\hline \multicolumn{11}{|c|}{ Peripheral blood } \\
\hline PMN & - & - & + & - & - & + & - & - & - & - \\
\hline Mono & - & - & - & + & - & + & - & - & + & - \\
\hline
\end{tabular}

Positivity was defined as a minimum of seven out of 10 positive results. 


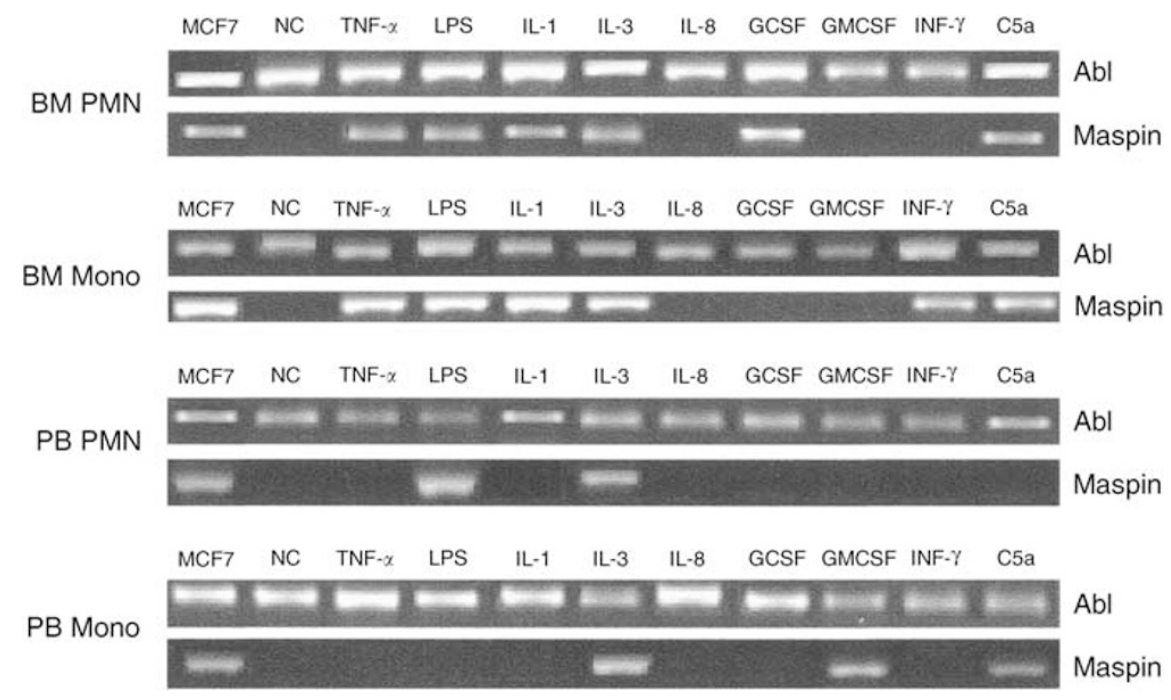

Figure 2 Electrophoretic analysis in a 2\% agarose gel of maspin RT-PCR fragments obtained after incubation of bone marrow and peripheral blood PMN and Mono with the indicated cytokines. ABL: Abelson transcript, this sequence was used as housekeeping gene; NC: negative control, cells incubated with culture medium alone.

1997; Jung et al, 1998; Jung et al, 1999; Ruud et al, 1999; Krüger et al, 2001; Jiang et al, 2002).

In this study, we first compared RT-PCR detection of the two breast cancer-specific markers maspin and MAM for sensitivity and specificity. Both of the markers demonstrated similar capacities to detect isolated tumour cells (about 1 out of $10^{7}$ ), and high specificity, not producing positive results in samples obtained from healthy donors. However, subsequent testing of maspin and MAM expression in leukocyte samples from patients with haematological/inflammatory disorders indicated that maspin mRNA was expressed in $40 \%$ of these samples whereas MAM was never detectable.

Expression of epithelial markers in the bone marrow of patients with nonepithelial tumours or inflammatory diseases has previously been reported (Zippelius et al, 1997; Zach et al, 1999; Ballestrero et al, 2001; Krüger et al, 2001). Therefore, we evaluated in normal blood cells the possibility of a cytokine-induced expression of maspin and MAM.

In particular, we evaluated the effect on blood cells of a panel of known leukocyte-activating cytokines including chemotactic factors (C5a, IL-8), LPS, proinflammatory cytokines (TNF- $\alpha$, IL-1 $\beta$ ) and growth factors (IL-3, GM-CSF, G-CSF).

All of the stimuli, except for IL-8, were able to induce maspin mRNA expression in normal bone marrow PMN or Mono cells (Table 2). Conversely, only LPS, C5a, IL-3, G-CSF and GM-CSF induced maspin expression in peripheral blood cells. The reasons for the different expression pattern of maspin between bone marrow- and peripheral blood-derived cells are unclear, and may involve a reduced sensitivity to cytokine-mediated gene induction in terminally differentiated cells. Interestingly, while maspin messenger became detectable in PMN after a few hours of exposure to the activating stimuli, maspin expression in Mono cells required a prolonged stimulation. On the contrary, the MAM gene was never inducible by any of the cytokines used in the stimulation experiments.

These results provide an explanation for the detection of maspin mRNA in the peripheral blood and bone marrow samples of patients with haematological diseases and inflammation. Besides, they suggest that maspin should be considered an epithelial marker with low specificity, whereas MAM may represent a more specific marker for the detection of isolated tumour cells in peripheral blood or bone marrow samples.

However, we found that MAM expression, similar to maspin although to a lesser extent, is induced in normal leukocytes by apheretic procedures (MAM and maspin were positive, respectively, in 10 and $30 \%$ of apheretic products from normal donors with negative peripheral blood before apheretic procedure, data not shown). This observation is consistent with the previous observations by Krüger et al (2001), who found MAM expression in $7 \%$ of clinical samples of bone marrow and leukapheresis products obtained from patients without epithelial cancer both in basal condition and under stimulation by several cytokines, including G- and GM-CSF, IL-3, IL-1 and INF- $\tilde{a}$. The reason for this effect is not understood, but since MAM is not inducible by cytokines, at least in our in vitro model, other mechanisms such as mechanical stress or reagents used during this procedure may play a role in this context.

This observation suggests that the apheretic procedure per se may be sufficient to upregulate in leukocytes markers other than maspin, through a mechanism that is possibly not cytokinemediated. Thus, RT-PCR detection of isolated tumour cells on apheretic products may be unreliable.

In conclusion, our data suggest that MAM is more specific than maspin and should be considered a reliable epithelial marker for the detection of disseminated tumour cells in patients' samples, probably with the exception of apheresis products. Furthermore, these data suggest that several factors possibly responsible for an ectopic gene expression should be taken into account in the validation process of new molecular markers.

\section{ACKNOWLEDGEMENTS}

This work was supported by Progetto FIRB n. RBAU01THPL and by a grant from Università di Genova Contributo Ricerca di Ateneo 2002.

\section{REFERENCES}

Ballestrero A, Coviello DA, Garuti A, Nencioni A, Famà A, Rocco I, Bertorelli R, Ferrando F, Gonella R, Patrone F (2001) Reverse-transcriptase polymerase chain reaction of the maspin gene in the detection of bone marrow breast carcinoma cell contamination. Cancer 92: 2030-2035 
Braun S, Pantel K, Müller P, Janni W, Hepp F, Kentenich CR, Gastroph S, Wischnik A, Dimpfl T, Kindermann G, Riethmuller G, Schlimok G (2000) Cytokeratin-positive cells in the bone marrow and survival of patients with stage I, II or III breast cancer. $N$ Engl J Med 342: 525-533

Cher M, Biliran Jr HR, Bhagat S, Meng Y, Che M, Lockett J, Abrams J, Fridman R, Zachareas M, Sheng S (2003) Maspin expression inhibits osteolysis, tumor growth, and angiogenesis in a model of prostate cancer bone metastasis. Proc Natl Acad Sci USA 100: 7847-7852

Corradini P, Voena C, Astolfi M, Delloro S, Pilotti S, Arrigoni G, Bregni M, Pileri A, Gianni AM (2001) Maspin and mammaglobin genes are specific markers for RT-PCR detection of minimal residual disease in patients with breast cancer. Ann Oncol 12: 1693-1698

Cote RJ, Rosen PP, Lesser ML, Old LJ, Osborne MP (1991) Prediction of early relapse in patients with operable breast cancer by detection of occult bone marrow micrometastases. J Clin Oncol 9: 1749-1756

Diel IJ, Kaufmann M, Costa SD, Holle R, von Minckwitz G, Solomayer EF, Kaul S, Bastert G (1996) Micrometastatic breast cancer cells in bone marrow at primary surgery: prognostic value in comparison with nodal status. J Natl Cancer Inst (Bethesda) 88: 1652-1658

Gebauer G, Fehm T, Merkle E, Beck EP, Lang N, Jager W (2001) Epithelial cells in bone marrow of breast cancer patients at time of primary surgery: clinical outcome during long-term follow-up. J Clin Oncol 19: $3669-3674$

Grünewald K, Haun M, Fiegl M, Urbanek M, Muller-Holzner E, Massoner A, Riha K, Propst A, Marth C, Gastl G (2002) Mammaglobin expression in gynecologic malignancies and malignant effusions detected by nested reverse transcriptase-polymerase chain reaction. Lab Invest 82: $1115-1147$

Grünewald K, Haun M, Urbanek M, Fiegl M, Müller-Holzner E, Gunsilius E, Dünser M, Marth C, Gasttl G (2000) Mammaglobin gene expression: a superior marker of breast cancer cells in peripheral blood in comparison to epidermal growth-factor receptor and cytokeratin-19. Lab Invest 80: $1071-1077$

Harbeck N, Untch M, Pache L, Eiermann W (1994) Tumour cell detection in the bone marrow of breast cancer patients at primary therapy: results of a 3-year median follow-up. Br J Cancer 69: 566-571

Jiang WG, Martin TA, Mansel RE (2002) Molecular detection of micrometastasis in breast cancer. Crit Rev Oncol Hematol 43: 13-31

Jung R, Krüger W, Hosch S, Holweg M, Kröger N, Gutensohn K, Wagener C, Neumaier M, Zander AR (1998) Specificity of reverse transcriptase polymerase chain reaction assays designed for the detection of circulating cancer cells is influenced by cytokines in vivo and in vitro. Br J Cancer 78: $1194-1198$

Jung R, Petersen K, Krüger W, Wolf M, Wagener C, Zander A, Neumaier M (1999) Detection of micrometastasis by cytokeratin 20 RT-PCR is limited due to stable background transcription in granulocytes. Br J Cancer 81: $870-873$

Krüger WH, Jung R, Detlefsen B, Mumme S, Badbaran A, Brandner J, Renges H, Kröger N, Zander AR (2001) Interference of cytocheratin-20 and mammaglobin-reverse-transcriptase polymerase chain reaction for the detection of disseminated cancer cells. Med Oncol 18: 33-38

Liu J, Yin S, Reddy N, Spencer C, Sheng S (2004) Bax mediates the apoptosis-sensitizing effect of maspin. Cancer Res 64: 1703-1711

López-Guerrero JA, Gilabert PB, González EB, Alonso MAS, Pérez JP, Talens AS, Oraval EA, de la Rubia Comos J, Boix SB (1999) Use of reverse-transcriptase polymerase chain reaction for carcinoembryonic antigen, cytokeratin 19, and maspin in the detection of tumor cells in leukapheresis products from patients with breast cancer: comparison with immunocytochemistry. J Hematother 8: 53-61

Luppi M, Morselli M, Bandieri E, Federico M, Marasca R, Barozzi P, Ferrari MG, Savarino M, Frassoldati A, Torelli G (1996) Sensitive detection of circulating breast cancer cells by reverse-transcriptase polymerase chain reaction of maspin gene. Ann Oncol 7: 619-624

Merrie AEH, Yun K, Gunn J, Phillips LV, McCall JL (1999) Analysis of potential markers for detection of submicroscopic lymph node metastases in breast cancer. Br J Cancer 80: 2019-2024
Miettinen OS (1970) Estimation of relative risk from individually matched series. Biometrics 26: $75-86$

Min CJ, Tafra L, Verbanac KM (1998) Identification of superior markers for polymerase chain reaction detection of breast cancer metastases in sentinel lymph nodes. Cancer Res 58: $4581-4584$

Ozbas S, Dafydd H, Purushotham AD (2003) Bone marrow micrometastasis in breast cancer. Br J Surg 90: 290-301

Pantel K, Müller V, Auer M, Nusser N, Harbeck N, Braun S (2003) Detection and clinical implications of early systemic tumor cell dissemination in breast cancer. Clin Cancer Res 9: 6326-6334

Pemberton PA, Tipton AR, Pavloff N, Smith J, Erickson JR, Mouchabeck ZM, Kiefer MC (1997) Maspin is an intracellular serpin that partitions into secretory vesicles and is present at the cell surface. J Histochem Cytochem 45: $1697-1706$

Ruud P, Fodstad O, Hovig E (1999) Identification of a novel cytokeratin 19 pseudogene that may interfere with reverse transcriptase-polymerase chain reaction assays used to detect micrometastatic tumor cells. Int $J$ Cancer 80: $119-125$

Sheng S, Carey J, Seftor E, Dias L, Hendrix MJC, Sager R (1996) Maspin acts at the cell membrane to inhibit invasion and motility of mammary and prostate carcinoma cells. Proc Natl Acad Sci USA 93: 11669-11674

Silva AL, Tome MJ, Correia AE, Passos-Coelho JL (2002) Human mammaglobin RT-PCR assay for detection of occult breast cancer cells in hematopoietic products. Ann Oncol 13: $422-429$

Singletary SE, Allred C, Ashley P, Bassett LW, Berry D, Bland KI, Borgen PI, Clark G, Edge S B, Hayes DF, Hughes LL, Hutter RV, Morrow M, Page DL, Recht A, Theriault RL, Thor A, Weaver DL, Wieand HS, Greene FL (2002) Revision of the American Joint Committee on Cancer staging system for breast cancer. J Clin Oncol 20: 3628-3636

Sjodin A, Guo D, Hofer PA, Henriksson R, Hedman H (2003) Mammaglobin in normal human sweat glands and human sweat gland tumors. J Invest Dermatol 121: 428-429

Smith BM, Slade MJ, English J, Graham H, Luchtenborg M, Sinnett HD, Cross NC, Coombes RC (2000) Response of circulating tumor cells to systemic therapy in patients with metastatic breast cancer: comparison of quantitative polymerase chain reaction and immunocytochemical techniques. J Clin Oncol 18: 1432-1439

Stathopoulou A, Vlachonikolis I, Mavroudis D, Perraki M, Kouroussis C, Apostolaki S, Malamos N, Kakolyris S, Kotsakis A, Xenidis N, Reppa D, Georgoulias V (2002) Molecular detection of cytokeratin-19-positive cells in the peripheral blood of patients with operable breast cancer: evaluation of their prognostic significance. J Clin Oncol 20: 3404-3412

Suchy B, Austrup F, Driesel G, Eder C, Kusiak I, Uciechowski P, Grill HJ, Giesing M (2000) Detection of mammaglobin expressing cells in blood of breast cancer patients. Cancer Lett 158: $171-178$

Terstappen LW, Rao C, Gross S, Weiss AJ (2000) Peripheral blood tumour cell load reflects the clinical activity of the disease in patients with carcinoma of the breast. Int J Oncol 17: 573-578

Watson MA, Fleming TP (1996) Mammaglobin, a mammary-specific member of the uteroglobin gene family, is overexpressed in human breast cancer. Cancer Res 56: $860-865$

Zach O, Kasparu H, Krieger O, Hehenwarter W, Girschikofsky M, Lutz D (1999) Detection of circulating mammary carcinoma cells in the peripheral blood of breast cancer patients via a nested reverse transcriptase polymerase chain reaction assay for mammaglobin mRNA. J Clin Oncol 17: 2015-2019

Zehentner BK, Carter D (2004) Mammaglobin: a candidate diagnostic marker for breast cancer. Clin Biochem 37: 249-257

Zhang M, Volpert O, Shi YH, Bouck N (2000) Maspin is an angiogenesis inhibitor. Nat Med 6: 196-199

Zippelius A, Kufer P, Honold G, Kollermann MW, Oberneder R, Schlimok G, Riethmuller G, Pantel K (1997) Limitations of reverse-transcriptase polymerase chain reaction analyses for detection of micrometastatic epithelial cancer cells in bone marrow. J Clin Oncol 15: 2701-2708

Zou Z, Anisowicz A, Hendrix MJC, Thor A, Neveu M, Sheng S, Rafidi K, Seftor E, Sager R (1994) Maspin, a serpin with tumor-suppressing activity in human mammary epithelial cells. Science 263: 526-529 